Original article

\title{
Evaluation of sodium hypochlorite efficiency on the elimination of Pseudomonas aeruginosa biofilm using two methods
}

\author{
Khaddouj Amzil ${ }^{1}$, Fatima Hamadi ${ }^{1}$, Rachida Mimouni ${ }^{1}$, Hassan Latrache ${ }^{2}$, Khadija Azelmad ${ }^{1}$, Youssef Najih ${ }^{2}$, \\ Mustapha Mabrouki ${ }^{2}$ \\ ${ }^{1}$ University Ibn Zohr, Agadir, Morocco \\ ${ }^{2}$ Sultan Moulay Slimane University, Beni Mellal, Morocco
}

Received 12 May 2018, Revised 23 May 2019, Accepted 26 June 2019

C 2018, Amzil K., Hamadi F., Mimouni R., Latrache H., Azelmad K., Najih Y., Mabrouki M

(C) 2018, Russian Open Medical Journal

\begin{abstract}
Aims - The purposes of the present work were to study the biofilm formation of Pseudomonas aeruginosa on stainless steel (316 and 304) and to investigate the effectiveness of sodium hypochlorite with different concentrations after 5 min of treatment, against $P$. aeruginosa biofilm formed on the same substrata.

Methods - The methods used in this study were plate count method (PCM) and atomic force microscopy (AFM).

Results - The results obtained using PCM showed that bacteria adhered more to stainless steel 316 than stainless steel 304 . Furthermore, sodium hypochlorite was effective against cells of $P$. aeruginosa adhered to stainless steel 304 at the concentration of $0.5 \%$, but it was not effective against the ones adhered to stainless steel 316 until the concentration of $1 \%$. The AFM results appeared that some bacteria still adhered to two types of stainless steel after sodium hypochlorite treatment at all concentrations.

Conclusion - The type of surface and the disinfectant concentration have an effect on the efficiency of the disinfectant against biofilm. In addition the PCM and AFM do not give the same results.
\end{abstract}

Keywords: biofilm, Pseudomonas aeruginosa, stainless steel, atomic force microscopy, plate count method.

Cite as Amzil K, Hamadi F, Mimouni R, Latrache H, Azelmad K, Najih Y, Mabrouki M. Evaluation of sodium hypochlorite efficiency on the elimination of Pseudomonas aeruginosa biofilm using two methods. Russian Open Medical Journal 2019; 8: e0302.

Correspondence to Fatima Hamadi. Address: Laboratory of Microbial Biotechnology and Vegetal Protection, Faculty of Sciences, University Ibn Zohr, Agadir, Morocco. Fax: 212(0)828220100. E-mail \#1: ha_fatima@yahoo.fr. E-mail \#2: f.hamadi@uiz.ac.ma. Phone: +212(0)662331505.

\section{Introduction}

Pseudomonas aeruginosa is aubiquitous environmental bacterium. It is considered as one of the important opportunistic human pathogens, causing serious problems in food sectors. This bacterium was isolated from different surfaces $[1,2]$. It has the ability to attach to a variety of them, including the food processing environment, and form biofilm [3, 4]. This latter is defined as a biologically active matrix of cells and extracellular substances in association with a solid surface [5], and it is more resistant to sanitizing and antimicrobial agents [3]. The adhesion is considered the key step of biofilm formation and it is widely studied especially on the food contact surfaces [6-10]. This adhesion and consequently biofilm formation might be affected by physicochemical characteristics of the surfaces $[11,12]$, and by its topography and roughness [4, 13].

Cleaning and disinfection are the key way to prevent the contamination of the food contact surfaces and consequently food products. Moreover, the contamination of food-contact surfaces might lead to the persistence of pathogens in food processing environments [14], which must be a significant public health impact [15]. Several chemical agents were tested against biofilms of various microorganism cells such as peracetic acid [14, 16-19] and hydrogen peroxide [20]. The first one showed the ability to eliminate approximately $98 \%$ and $99 \%$ of viable $S$. aureus and $P$. aeruginosa, respectively, after $1 \mathrm{~min}$ as contact time but not the biofilm matrix [14], while the second one is considered an efficient disinfectant against biofilms [21]. In addition, Ozone was also evaluated against biofilm in many studies [22-26], which cannot lead to microorganism resistance [27].

The efficiency of disinfection operation depends on the microorganism, the disinfectant, the concentration of disinfectant, the contact time, the $\mathrm{pH}$, the temperature, etc. The relationship between the concentration of the disinfectant and the contact time should be considered to achieve a determined reduction of the microorganism $[28,29]$. Sodium hypochlorite is one of the chemical compounds used for bleaching or disinfecting different things including surfaces. Numerous works were done about its efficiency against biofilms [30-32] and contradictory results were obtained. Sodium hypochlorite was reported to be an effective disinfectant for biofilm inactivation [33]

Different methods are applied to quantify the number of adhered bacteria and the remained ones after treatment. These methods include McFarland turbidity test [18], swabbing method 
[34], microplate absorbance measurement [18], and plate count method. For this latter many techniques are used for biofilm dislodging from a surface such as ultrasonic [34, 35], shaking with beads [18] and vortexing [37]. In addition to that, many other techniques are used for biofilm visualization including epifluorescence microscopy [9, 37-39], scanning electron microscopy [35, 36, 40] and atomic force microscopy [41, 42]. Based on our best knowledge no study has compared between plate count method and atomic force microscopy.

The goals of this work were to study the $P$. aeruginosa biofilm formation on two types of stainless steel (316 and 304), and to investigate the ability of sodium hypochlorite to eliminate biofilm from two types of stainless steels using AFM and PCM methods.

\section{Material and Methods}

\section{Bacterium strain preparation of bacterial suspension}

The bacterium used in this study was Pseudomonas aeruginosa. This bacterium was isolated from a stainless steel surface, after cleaning and disinfecting procedures. The bacterium was grown at $37^{\circ} \mathrm{C}$ for 24 hours on Luria Bertani agar. This medium was made using the following components; $10 \mathrm{~g}$ tryptone, $5 \mathrm{~g}$ yeast extract, $10 \mathrm{~g} \mathrm{NaCl}$ and $15 \mathrm{~g}$ agar, and one liter of distilled water. After 24 hours of incubation, bacterial cells were scraped off the agar plates and harvested by centrifugation at $6500 \mathrm{rcf}$ for 15 minutes. Cells pellets were resuspended in KNO3 (0.1M) and adjusted by spectrophotometer to an optical density wave length angle of $600 \mathrm{~nm}$ of optical density approximately between 0.7 and 0.8 corresponding to $108 \mathrm{CFU} / \mathrm{ml}$.

\section{Substratum preparation}

The size of two types of stainless steel $(316$ / 304) surfaces was $1 \mathrm{~cm}$ per $1 \mathrm{~cm}$. These surfaces were immersed in the solution of absolute ethanol for 15 minutes. Then rinsed three times with distilled water, and they were autoclaved at $121^{\circ} \mathrm{C}$ for 20 minutes $[43,44]$.

\section{Disinfectant tested}

The disinfectant selected for this study was sodium hypochlorite ( $\mathrm{NaCLO}$ ), at four different concentrations which are $0.5 \%, 1 \%, 1.5 \%$, and $2 \%$.

\section{Biofilm formation test}

The sterilized surfaces were immersed in the Petri dishes containing the bacterial suspension, for 3 hours at $25^{\circ} \mathrm{C}$. After, the surfaces were rinsed three times by distilled and sterilized water to remove the non-attached bacteria. Then the surfaces were placed in Luria Bertani broth and incubated at $25^{\circ} \mathrm{C}$ for 24 hours [18, 39, 45, 46]. Three replicates were carried out for each experiment and only the numbers of colonies between 30 and 300 are included in the calculation of the number of the bacteria adhered to two stainless steels.

\section{Efficiency of sodium hypochlorite against biofilm cells}

The surfaces colonized by $P$. aeruginosa were rinsed three times to remove the non-adhered cells. Then, they were placed in Petri dishes containing sodium hypochlorite already prepared at diverse concentrations $(0.5 \%, 1 \%, 1.5 \%$ and $2 \%)$. After $5 \mathrm{~min}$ of contact, the surfaces were rinsed 3 times. They were after placed in the glass tubes containing $10 \mathrm{~mL}$ of sterile physiological saline, and sonicated at $35 \mathrm{kHz}$ for $10 \mathrm{~min}$ and vortexed [4, 35]. To quantify viable cells, bacteria were resuspended, serially diluted 10-fold with sterilized physiological saline and cultured on nutrient Agar at the temperature of $37^{\circ} \mathrm{C}$ for 24 hours $[45,47,48]$. Three replicates were carried out for each experiment.

\section{Atomic force microscopy analysis}

The topography images and roughness of both stainless steels colonized by $P$. aeruginosa biofilm and treated with sodium hypochlorite at different concentrations $(0.5 \%, 1 \%, 1.5 \%$, and 2 $\%$ ) were measured using Atomic Force Microscopy (Nanosurf flex AFM). The measurement was carried out with an easy scan 2 controller from Nanosurf. The tapping mode (Dynamic) in an ambient air environment was used for scanning and measuring. The Ra value, which is the arithmetic mean deviation of profile, is the most commonly used descriptor of surface roughness [49]. The Ra value was determined using the software easy scan 2 (three replicates)

\section{Statistical analysis}

Statistical analyses were performed using Software STATISTICA version 6 . Newman-keuls test was used to compare the means $\log _{10} \mathrm{UFC} / \mathrm{cm}^{2}$ of each surface before and after disinfection treatment $(P<0.05)$. The means presented in the figures with the same letters are not significantly different and the ones with distinct letters are significantly different.

\section{Results}

P. aeruginosa biofilm formation on two types of stainless steel

In the present work, the ability of $P$. aeruginosa to form biofilm on stainless steel 316 and stainless steel 304 was studied. Figure 1 presents the numbers of biofilm cells adhered to two substrata. The results obtained show that a number of $\log _{10} 6.78$ CFU. $\mathrm{cm}^{-2}$ of cells was adhered to stainless steel 304, whereas, a number of $\log _{10} 7.61 \mathrm{CFU} . \mathrm{cm}^{-2}$ adhered to stainless steel 316 . Based on statistical analysis there is a highly significant difference $(p<0.01)$ in the number of adhered bacteria to two stainless steel. In addition to this, Figure 2 shows the AFM images of $P$. aeruginosa biofilm formed on stainless steel 304 (Figure 2: C, D) and stainless steel 316 (Figure 2: G, H). These images appeared that the bacterial cells colonized different parts of two substrata by forming a mass of bacteria embedded in a matrix of exopolysaccharides (EPS).

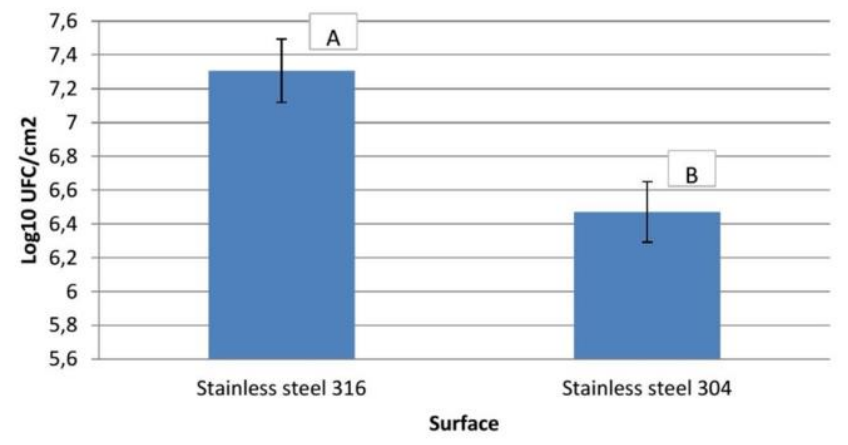

Figure 1. Numbers of biofilm cells adhered to stainless steel 304 and stainless steel 316 . 

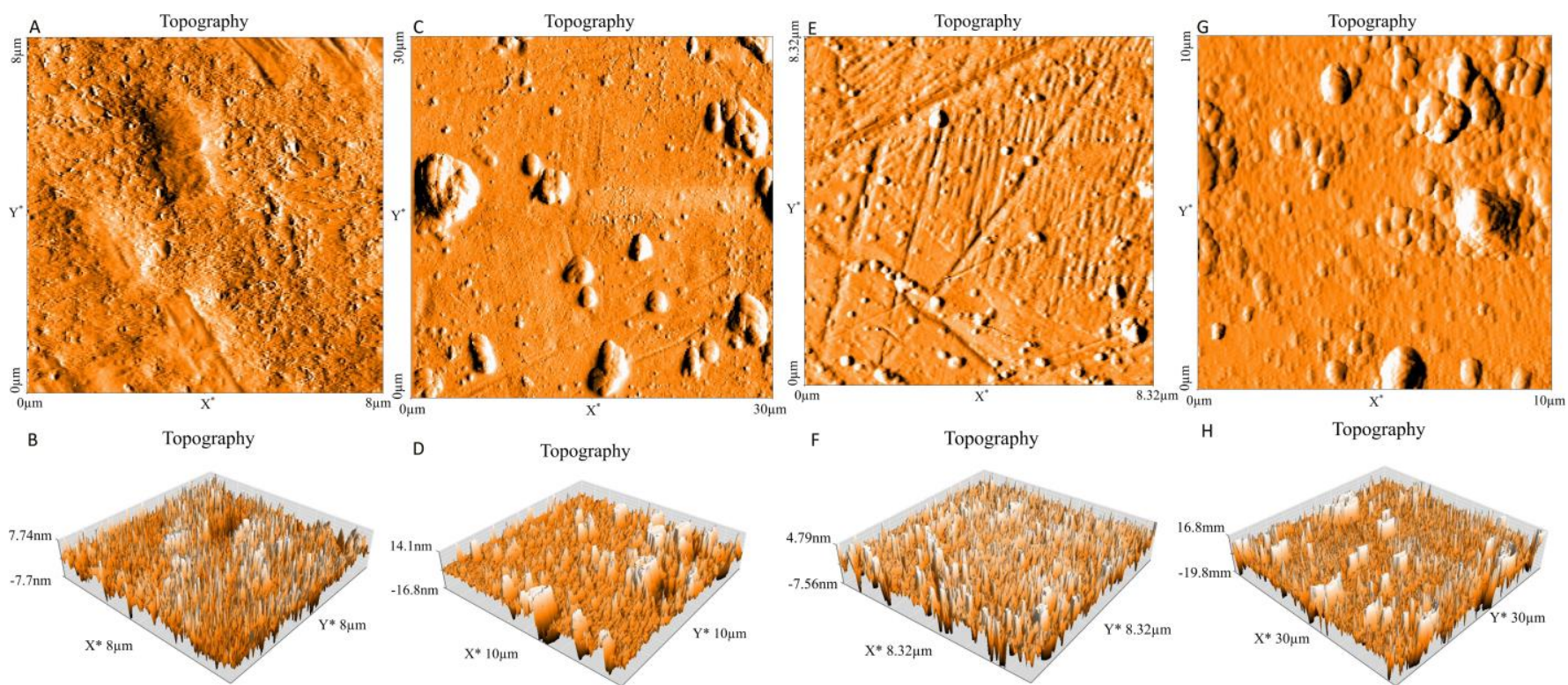

Figure 2. Topography (Three dimensional images) of stainless steel 304 (bare substrate) (A, B), stainless steel 304 (biofilm) (C, D), stainless steel 316 (bare substrate) $(E, F)$ and stainless steel 316 (biofilm) $(G, H)$.
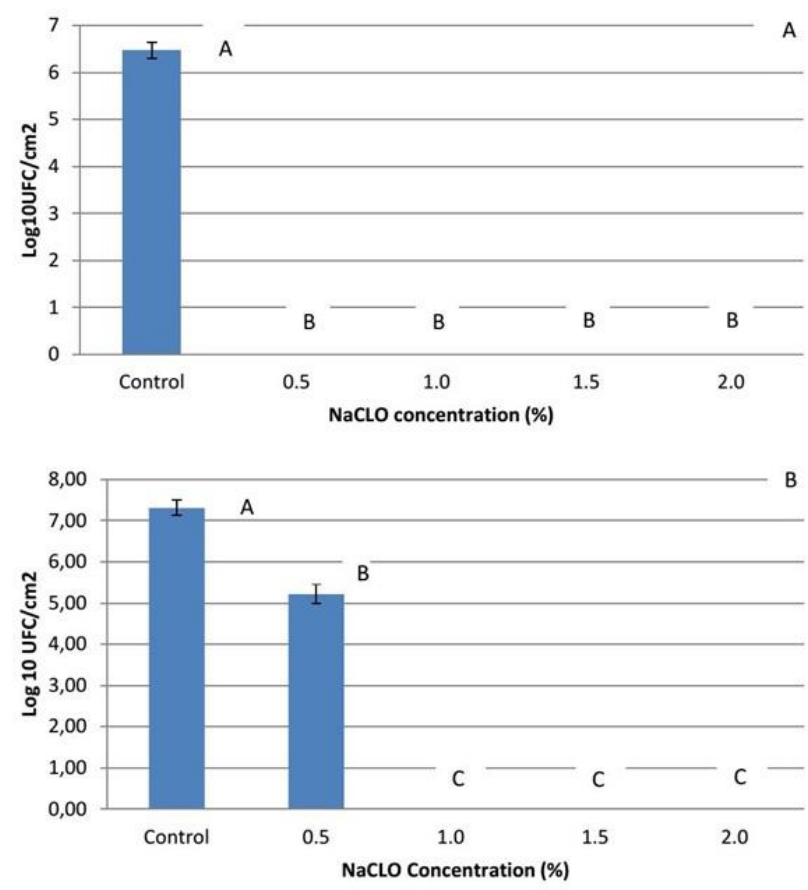

Figure 3. Number of biofilm cells adhered to stainless steel $304[\mathrm{~A}]$ and 316 [B] after sodium hypochlorite treatment. The Control represents the surface colonized with Biofilm.

Evaluation of Sodium Hypochlorite Ability to Eliminate Biofilm from Surfaces by using AFM and PCM methods

The ability of sodium hypochlorite to eliminate $P$. aeruginosa biofilm formed on stainless steel 304 and stainless steel 316 was investigated by using plate count method (PCM) and atomic force microscopy (AFM). The results presented in Figure 3 showed a highly significant difference in the number of biofilm cells attached to both stainless steel $(p<0.01)$ after treatment compared with the control
(Sodium hypochlorite concentration equal 0\%). Sodium hypochlorite was efficient against biofilm cells installed on stainless steel 304 at the concentration of $0.5 \%$ after 5 min of treatment, whilst it was not efficient against biofilm cells formed on stainless steel 316 under the same condition until the concentration of $1 \%$ (Figure 3). Whereas, the results obtained when evaluated using AFM (Figure 4), showed that the bacteria were left on both stainless steel (316 and 304) after sodium hypochlorite treatment especially at the concentrations of $0.5 \%$ and $1 \%$. But, the numbers of the persisted bacteria decreased at the concentrations of $1.5 \%$ and $2.0 \%$, indicating that the two methods (AFM and PCM) do not give the same results.

\section{Discussion}

The $P$. aeruginosa biofilm formation on the stainless steel 316 and stainless steel 304 was performed and the results demonstrated that a high number of $P$. aeuginosa cells have been adhered to stainless steel 316 than stainless steel 304 . This difference could be explained by the surfaces roughness as reported by Azelmad et al. [4] which showed that stainless steel $316(6.1 \pm 1.4 \mathrm{~nm})$ is rougher than stainless steel $304(2.7 \pm 0.1 \mathrm{~nm})$. Other works also reported that the bacterial adhesion increases by the increasing of the surface roughness $[4,40,50]$. In contrast, several studies showed that surface roughness has no effect on the bacterial adhesion [51, 52]. In addition to this, the bacterial adhesion to both stainless steel could also be explained by physicochemical characteristics of surfaces. According to Azelmad, Hamadi [4], stainless steel 316 has a hydrophilic surface, while stainless steel 304 has a hydrophobic one. Based on the physicochemical approach, the hydrophobic cells tend to attach to the hydrophobic substrate and the hydrophilic cells tend to attach to the hydrophilic substrate. This could explain the higher adhesion of $P$. aeruginosa which is also hydrophilic $[53,54]$ to stainless steel 316 than stainless steel 304 . Our results underlined that the bacteria adhere to a large extent on stainless steel 316 compared with stainless steel 304 which means that the surface type influences the bacterial adhesion. This is in agreement with studies of numerous researchers who also found that the rate of the adhered bacteria is influenced by the type of the surface [39, 55-58]. 
A Topography
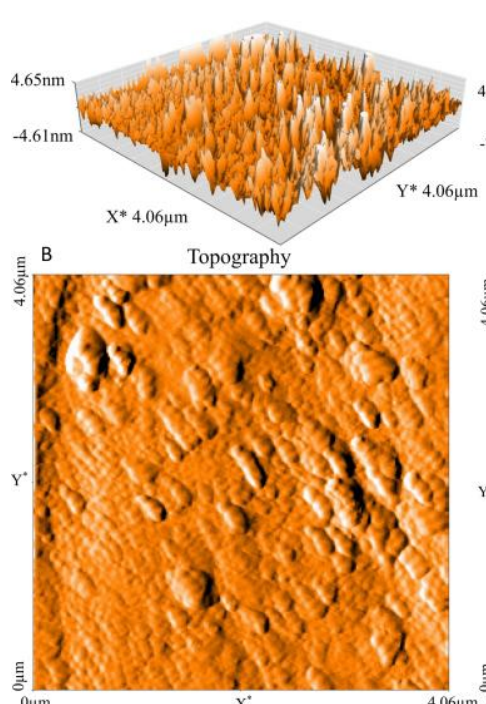
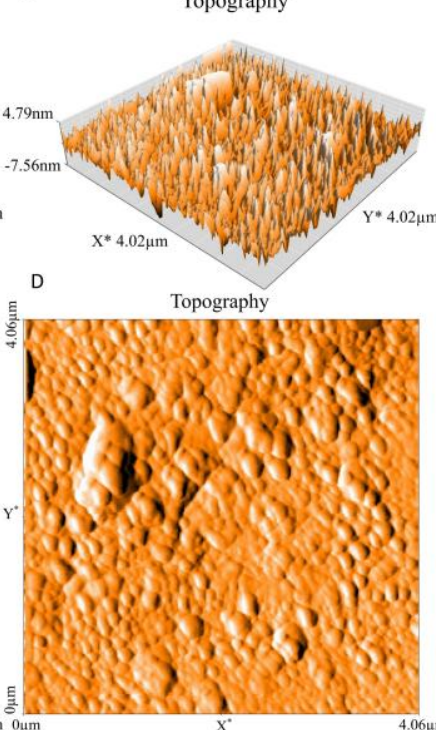

E
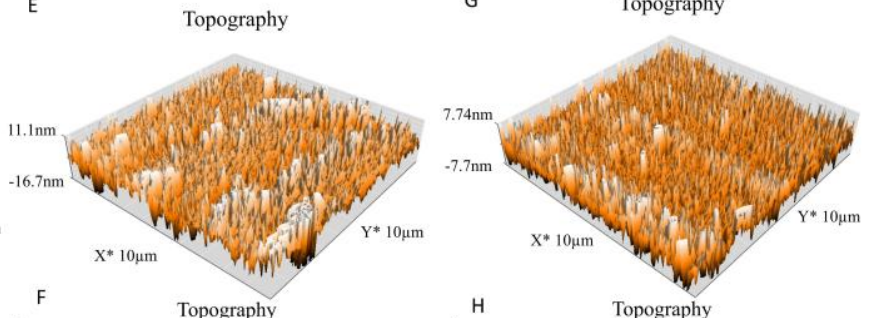
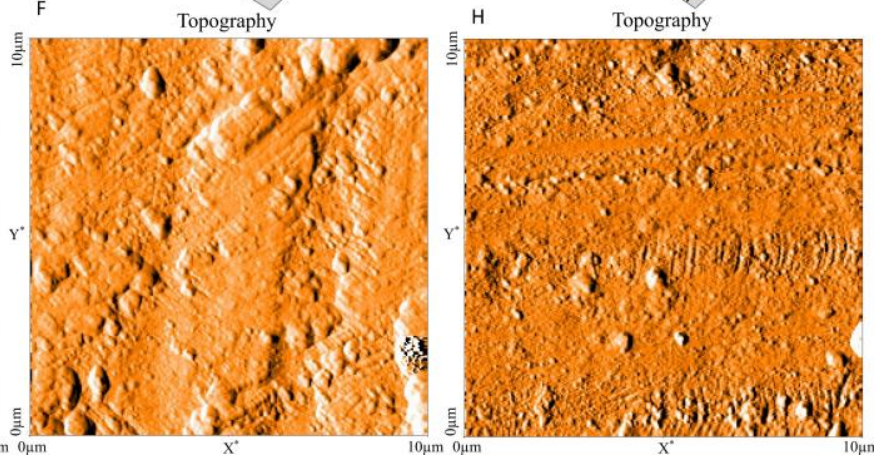

Figure 4. Topography (Three dimensional images) of stainless steel 304 colonized by $P$. aeruginosa biofilm and treated with sodium hypochlorite at concentration of $0.5 \%[A, B], 1 \%[C, D], 1.5 \%[E, F], 2 \%[G, H]$.
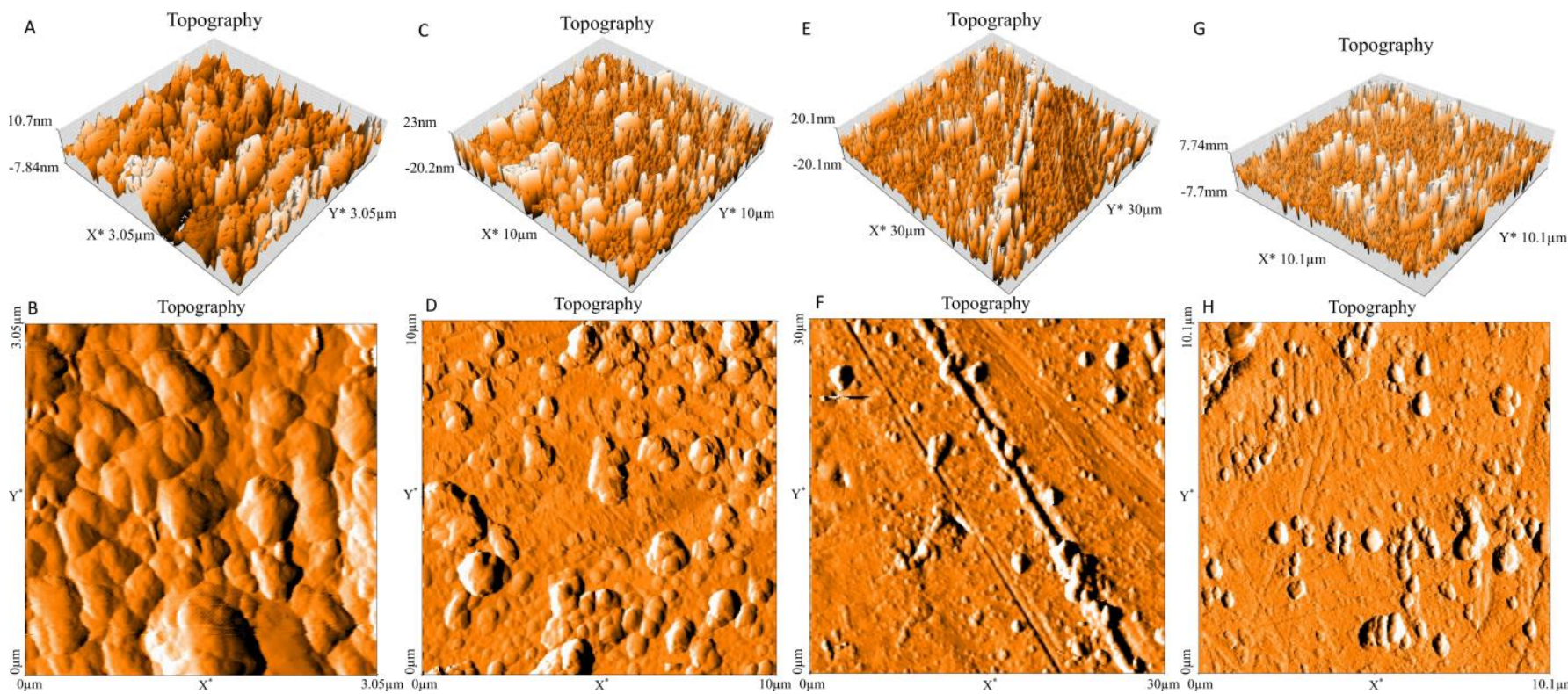

Figure 5. Topography (Three dimensional images) of stainless steel 316 colonized by $P$. aeruginosa biofilm and treated with sodium hypochlorite at concentration of $0.5 \%[A, B], 1 \%[C, D], 1.5 \%[E, F], 2 \%[G, H]$.

The $P$. aeruginosa biofilm formation was also assessed using AFM which confirms that this bacterium has the capacity to stick and form a biofilm on both stainless steels. This result is in agreement with the ones reported by other authors using AFM $[42,59]$ and scanning electron microscopy $[20]$.

The efficiency of sodium hypochlorite against $P$. aeruginosa biofilm formed on stainless steel surfaces was evaluated using AFM and PCM which pronounced opposite results. The absence of bacterial cells after sodium hypochlorite treatment in the case of the plate count method could be explained by the fact that bacteria might be dead, injury or none cultivate after treatment. Cabeça et al. [35] evaluated five disinfectants against biofilms cells by using plate count method and scanning electron microscopy, and they showed that sodium hypochlorite was the most effective disinfectant against these biofilms compared to others such as biguanide and peracetic acid. While, their results obtained by scanning electron microscopy observations revealed that the bacteria still adhered to stainless steel after all concentrations treatment which is in agreement with our findings. Wirtanen et al. [60] reported that chlorine-based disinfectant was efficient against biofilms of Pseudomonas aeruginosa and Pseudomonas fragi formed on stainless steel 304, by using conventional cultivation, impedimetry and epifluorescence microscopy. In addition to that, the coverage of this surface by the biofilm was decreased better after this treatment. Other studies also investigated the efficiency of disinfectants such as peracetic acid, chlorhexidine, benzalkonium chloride, alkyldiaminoethyl glycine and sodium hypochlorite against biofilm cells [18, 61-63]. Takeo et al. [62] 
reported that eradication of $P$. aeruginosa biofilm cells by disinfectants required more time than that in suspension and that the increasing concentration of disinfectant raised the antimicrobial effects against biofilm cells. Whilst, Martin-Espada et al [18] evaluated the peracetic acid by microplate absorbance measurements and McFarland turbidity. Their results showed that peracetic acid kills $100 \%$ of Pseudomonas aeruginosa biofilm installed on polystyrene at the concentration of $1.61 \%$ after 15 min of treatment.

\section{Conclusion}

The results of the present work reveal that $P$. aeruginosa has the ability to form the biofilm on stainless steel 316 and stainless steel 304. The maximum of adhered cells was observed on stainless steel 316 compared with stainless steel 304 . In addition, sodium hypochlorite is more efficient against viable cells adhered to stainless 304 at $0.5 \%$ of sodium hypochlorite after $5 \mathrm{~min}$ of treatment, whilst this disinfectant was not efficient against one installed on stainless steel 316 until the concentration of 1\% at the same time of treatment. In contrast, AFM images appeared that some bacterial cells still attached to two types of stainless steel after treatment at all concentrations applied.

\section{Acknowledgements}

The authors thank Dr. Mohammed Ait Hamza for his help in the statistical analysis and Hicham Mechqoq for his help in the images treatment.

\section{Conflict of Interest}

The authors declare that they have no conflict of interest.

\section{Ethical approval}

This article does not contain any studies with human participants or animals performed by any of the authors.

\section{References}

1. Lyczak JB, Cannon CL, Pier GB. Establishment of Pseudomonas aeruginosa infection: lessons from a versatile opportunist. Microbes Infect 2000; 2(9): 1051-1060. https://doi.org/10.1016/S12864579(00)01259-4.

2. Brooks SE, Walczak MA, Hameed R, Coonan P. Chlorhexidine resistance in antibiotic-resistant bacteria isolated from the surfaces of dispensers of soap containing chlorhexidine. Infect Control Hosp Epidemiol 2002; 23(11): 692-695. https://doi.org/10.1086/501996.

3. Bremer PJ, Monk I, Osborne CM, Survival of Listeria monocytogenes attached to stainless steel surfaces in the presence or absence of Flavobacterium spp. J Food Prot 2001; 64(9): 1369-1376. https://doi.org/10.4315/0362-028X-64.9.1369.

4. Azelmad K, Hamadia F, Mimounia R, Amzila K, Latracheb H, Mabrouki $M$, et al. Adhesion of Staphylococcus aureus and Staphylococcus xylosus to materials commonly found in catering and domestic kitchens. Food Control 2017; 73(B): 156-163. https://doi.org/10.1016/j.foodcont.2016.07.044.

5. Garrett TR, Bhakoo M, Zhang Z. Bacterial adhesion and biofilms on surfaces. Progress in Natural Science 2008; 18(9): 1049-1056. https://doi.org/10.1016/j.pnsc.2008.04.001.

6. Frank JF. Microbial attachment to food and food contact surfaces. Adv Food Nutr Res 2001; 43: 319-370. https://doi.org/10.1016/S10434526(01)43008-7.

7. Bower CK, McGuire J, Daeschel MA. The adhesion and detachment of bacteria and spores on food-contact surfaces. Trends in Food Science \&
Technology 1996; 7(5): 152-157. https://doi.org/10.1016/09242244(96)81255-6.

8. Silva $\mathrm{S}$, Teixeira $\mathrm{P}$, Oliveira $\mathrm{R}$, Azeredo J. Adhesion to and viability of Listeria monocytogenes on food contact surfaces. J Food Prot 2008 71(7): 1379-1385. https://doi.org/10.4315/0362-028X-71.7.1379.

9. Teixeira, P, Lima JC, Azeredo J, Oliveira R. Note. Colonisation of bench cover materials by Salmonella typhimurium. Food Science and Technology International 2007; 13(1): 5-10. https://doi.org/10.1177/1082013207075157.

10. Mafu AA, Plumety C, Deschênes L, Goulet J. Adhesion of pathogenic bacteria to food contact surfaces: Influence of $\mathrm{pH}$ of culture. Int J Microbiol 2011. 2011: 972494. https://doi.org/10.1155/2011/972494.

11. Oliveira R, Azeredo J, Teixeira P. The importance of physicochemical properties in biofilm formation and activity. In: Biofilms in wastewater treatment: an interdisciplinary approach. S. Wuertz, P.L. Bishop, P.A. Wilderer, eds. London, UK: IWA, 2003: 211-231.

12. Oliveira R, Azeredo J, Teixeira P, Fonseca AP. The role of hydrophobicity in bacterial adhesion. In: Biofilm community and interactions: chance or necessity? P. Gilbert, D. Allison, M. Brading, J. Verran, J. Walker, eds. Cardiff: Bioline, 2001: 11-22. https://pdfs.semanticscholar.org/bfc0/fe4c4caf9cc3bde2f57c7c7d4ab 6f70eddb7.pdf.

13. Medilanski E, Kaufmann K, Wick LY, Wanner O, Harms H, Influence of the surface topography of stainless steel on bacterial adhesion. Biofouling 2002; 18(3): 193-203. https://doi.org/10.1080/08927010290011370.

14. Toté K, Horemans T, Vanden Berghe D, Maes L, Cos P. Inhibitory effect of biocides on the viable masses and matrices of Staphylococcus aureus and Pseudomonas aeruginosa biofilms. Appl Environ Microbiol 2010; 76(10): 3135-3142. https://doi.org/10.1128/AEM.02095-09.

15. Bridier A, Sanchez-Vizuete $P$, Guilbaud M, Piard JC, Naïtali M, Briandet R. Biofilm-associated persistence of food-borne pathogens. Food Microbiol 2015; 45(Pt $\quad$ B): $167-178$ https://doi.org/10.1016/j.fm.2014.04.015.

16. Marques, S.C., Rezende JGOS, Alves LAF, Silva BC, Alves E, Abreu LR, et al. Formation of biofilms by Staphylococcus aureus on stainless steel and glass surfaces and its resistance to some selected chemical sanitizers. Braz J Microbiol 2007; 38(3): 538-543. https://doi.org/10.1590/S1517-83822007000300029.

17. Salvia AC, Teodoro GR, Balducci I, Koga-Ito CY, Oliveira SH. Effectiveness of $2 \%$ peracetic acid for the disinfection of gutta-percha cones. Braz Oral Res 2011; 25(1): 23-27. https://doi.org/10.1590/S1806-83242011000100005.

18. Martín-Espada MC, D'orsb A, Bartoloméc MC, Pereirab M, SánchezFortún S. Peracetic acid disinfectant efficacy against Pseudomonas aeruginosa biofilms on polystyrene surfaces and comparison between methods to measure it. LWT-Food Science and Technology 2014; 56(1): 58-61. https://doi.org/10.1016/i.lwt.2013.11.013.

19. Mosteller TM, Bishop JR. Sanitizer efficacy against attached bacteria in a milk biofilm. J Food Prot 1993; 56(1): 34-41. https://doi.org/10.4315/0362-028X-56.1.34.

20. DeQueiroz GA, Day DF. Antimicrobial activity and effectiveness of a combination of sodium hypochlorite and hydrogen peroxide in killing and removing Pseudomonas aeruginosa biofilms from surfaces. J App Microbiol 2007; 103(4): 794-802. https://doi.org/10.1111/i.13652672.2007.03299.x.

21. De Carvalho CC. Biofilms: recent developments on an old battle. Recent Pat Biotechnol 2007; 1(1): 49-57. https://doi.org/10.2174/187220807779813965.

22. Dosti B, Guzel-seydim Z, Greene AK. Effectiveness of ozone, heat and chlorine for destroying common food spoilage bacteria in synthetic media and biofilms. International Journal of Dairy Technology 2005; 58(1): 19-24. https://doi.org/10.1111/j.1471-0307.2005.00176.x.

23. Robbins JB, Fisher CW, Moltz AG, Martin SE, Elimination of Listeria monocytogenes biofilms by ozone, chlorine, and hydrogen peroxide. $J$ 
Food Prot 2005; 68(3): 494-498. https://doi.org/10.4315/0362-028X68.3.494.

24. Huth KC, Quirling M, Maier S, Kamereck K, Alkhayer M, Paschos E, et al. Effectiveness of ozone against endodontopathogenic microorganisms in a root canal biofilm model. Int Endod J 2009; 42(1): 3-13. https://doi.org/10.1111/j.1365-2591.2008.01460.x.

25. Hems RS, Gulabivala K, Ng YL, Ready D, Spratt DA. An in vitro evaluation of the ability of ozone to kill a strain of Enterococcus faecalis. Int Endod J 2005; 38(1): 22-29. https://doi.org/10.1111/j.1365-2591.2004.00891.x.

26. Cabo M, Herrera JJ, Crespo MD, Pastoriza L. Comparison among the effectiveness of ozone, nisin and benzalkonium chloride for the elimination of planktonic cells and biofilms of Staphylococcus aureus CECT4459 on polypropylene. Food Control 2009; 20(5): 521-525. https://doi.org/10.1016/i.foodcont.2008.08.002.

27. Pascual A, Llorca I, Canut A. Use of ozone in food industries for reducing the environmental impact of cleaning and disinfection activities. Trends in Food Science \& Technology 2007; 18(1): S29-S35. https://doi.org/10.1016/j.tifs.2006.10.006.

28. Chick H, An investigation of the laws of disinfection. J Hyg (Lond) 1908; 8(1): 92-158. https://doi.org/10.1017/S0022172400006987.

29. Watson HE. A note on the variation of the rate of disinfection with change in the concentration of the disinfectant. J Hyg (Lond) 1908; 8(4): 536-542. https://doi.org/10.1017/S0022172400015928.

30. Prabhakar J, Senthilkumar M, Priya MS, Mahalakshmi K, Sehgal PK, Sukumaran VG. Evaluation of antimicrobial efficacy of herbal alternatives (Triphala and green tea polyphenols), MTAD, and 5\% sodium hypochlorite against Enterococcus faecalis biofilm formed on tooth substrate: an in vitro study. J Endod 2010; 36(1): 83-86. https://doi.org/10.1016/j.joen.2009.09.040.

31. Liu H, Wei X, Ling J, Wang W, Huang X. Biofilm formation capability of Enterococcus faecalis cells in starvation phase and its susceptibility to sodium hypochlorite. J Endod 2010; 36(4): 630-635. https://doi.org/10.1016/j.joen.2009.11.016.

32. Sena NT, Gomes BP, Vianna ME, Berber VB, Zaia AA, Ferraz CC, et al. In vitro antimicrobial activity of sodium hypochlorite and chlorhexidine against selected single-species biofilms. Int Endod J 2006; 39(11): 878885. https://doi.org/10.1111/j.1365-2591.2006.01161.x.

33. Ozdemir HO, Buzoglu HD, Calt S, Stabholz A, Steinberg D. Effect of ethylenediaminetetraacetic acid and sodium hypochlorite irrigation on Enterococcus faecalis biofilm colonization in young and old human root canal dentin: in vitro study. J Endod 2010; 36(5): 842-846. https://doi.org/10.1016/j.joen.2010.01.008.

34. Oulahal-Lagsir N, Martial-Gros A, Bonneau M, Blum L. Ultrasonic methodology coupled to ATP bioluminescence for the non-invasive detection of fouling in food processing equipment - validation and application to a dairy factory. J Appl Microbiol 2000; 89(3): 433-441. https://doi.org/10.1046/i.1365-2672.2000.01132.x.

35. Cabeça TK, Pizzolitto AC, Pizzolitto EL. Activity of disinfectants against foodborne pathogens in suspension and adhered to stainless steel surfaces. Braz J Microbiol 2012; 43(3): 1112-1119. https://doi.org/10.1590/S1517-83822012000300038.

36. Ziech RE, Perin AP, Lampugnani C, Sereno MJ, Viana C, Soares VM, et al. Biofilm-producing ability and tolerance to industrial sanitizers in Salmonella spp. isolated from Brazilian poultry processing plants. LWTFood Science and Technology 2016; 68: 85-90. https://doi.org/10.1016/j.lwt.2015.12.021.

37. Parkar SG, Flint SH, Brooks JD. Evaluation of the effect of cleaning regimes on biofilms of thermophilic bacilli on stainless steel. J Appl Microbiol 2004; 96(1): 110-116. https://doi.org/10.1046/j.13652672.2003.02136.x

38. Simões M, Simões LC, Cleto $S$, Pereira MO, Vieira MJ. The effects of a biocide and a surfactant on the detachment of Pseudomonas fluorescens from glass surfaces. Int J Food Microbiol 2008; 121(3): 335341. https://doi.org/10.1016/j.ijfoodmicro.2007.11.041.
39. Abdallah M, Khelissa O, Ibrahim A, Benoliel C, Heliot L, Dhulster P, et al. Impact of growth temperature and surface type on the resistance of Pseudomonas aeruginosa and Staphylococcus aureus biofilms to disinfectants. Int J Food Microbiol 2015; 214: 38-47. https://doi.org/10.1016/j.ijfoodmicro.2015.07.022.

40. Bohinc K, Dražić $G$, Fink R, Oder M, Jevšnik $M$, Nipič $D$, et al. Available surface dictates microbial adhesion capacity. International Journal of Adhesion and Adhesives 2014; 50: 265-272. https://doi.org/10.1016/i.ijadhadh.2014.01.027.

41. Oh YJ, Lee NR, Jo W, Jung WK, Lim JS Effects of substrates on biofilm formation observed by atomic force microscopy. Ultramicroscopy 2009; 109(8): 874-880. https://doi.org/10.1016/i.ultramic.2009.03.042.

42. Beech IB, Smith JR, Steele AA, Penegar I, Campbell SA. The use of atomic force microscopy for studying interactions of bacterial biofilms with surfaces. Colloids Surf B Biointerfaces 2002; 23(2-3): 231-247. https://doi.org/10.1016/S0927-7765(01)00233-8.

43. Akbas MY, Cag S. Use of organic acids for prevention and removal of Bacillus subtilis biofilms on food contact surfaces. Food Sci Technol Int 2016; 22(7): 587-597. https://doi.org/10.1177/1082013216633545.

44. Hamadi F, Latrache $\mathrm{H}$, Asserne F, Elabed S, Zahir H, Koraichi I, et al., Quantitative adhesion of Staphylococcus aureus on stainless steel coated with milk. Food and Nutrition Sciences, 2013; 4(3): 299-304. https://doi.org/10.4236/fns.2013.43040.

45. Chavant $P$, Martinie B, Meylheuc T, Bellon-Fontaine MN, Hebraud M. Listeria monocytogenes LO28: surface physicochemical properties and ability to form biofilms at different temperatures and growth phases. Appl Environ Microbio 2002.; 68(2): $728-737$ https://doi.org/10.1128/AEM.68.2.728-737.2002.

46. Planchon S, Gaillard-Martinie B, Dordet-Frisoni E, Bellon-Fontaine MN, Leroy S, Labadie J, et al. Formation of biofilm by Staphylococcus xylosus. Int J Food Microbiol 2006; 109(1-2): 88-96. https://doi.org/10.1016/j.ijfoodmicro.2006.01.016.

47. Da Silva FC, Kimpara ET, Mancini MN, Balducci I, Jorge AO, Koga-Ito CY. Effectiveness of six different disinfectants on removing five microbial species and effects on the topographic characteristics of acrylic resin. $J$ Prosthodont 2008; 17(8): 627-633. https://doi.org/10.1111/i.1532849X.2008.00358.x.

48. Chaturongkasumrit $\mathrm{Y}$, Takahashi $\mathrm{H}$, Keeratipibul S, Kuda T, Kimura B. The effect of polyesterurethane belt surface roughness on Listeria monocytogenes biofilm formation and its cleaning efficiency. Food Control 2011; 22(12): 1893-1899. https://doi.org/10.1016/i.foodcont.2011.04.032.

49. Verran J, Rowe DL, Cole D, Boyd RD. The use of the atomic force microscope to visualise and measure wear of food contact surfaces. International Biodeterioration \& Biodegradation 2000; 46(2): 99-105. https://doi.org/10.1016/S0964-8305(00)00070-6.

50. Bohinc K, Dražić $G$, Abram A, Jevšnik $M$, Jeršek B, Nipič $D$, et al. Metal surface characteristics dictate bacterial adhesion capacity. International Journal of Adhesion and Adhesives 2016; 68: 39-46. https://doi.org/10.1016/j.ijadhadh.2016.01.008.

51. Rodriguez A, Autio WR, McLandsborough LA. Effect of surface roughness and stainless steel finish on Listeria monocytogenes attachment and biofilm formation. J Food Prot 2008; 71(1): 170-175. https://doi.org/10.4315/0362-028X-71.1.170.

52. Hilbert LR, Bagge-Ravn D, Kold J, Gram L. Influence of surface roughness of stainless steel on microbial adhesion and corrosion resistance. International Biodeterioration \& Biodegradation 2003; 52(3): 175-185. https://doi.org/10.1016/S0964-8305(03)00104-5.

53. Hamadi $\mathrm{F}$, Latrache $\mathrm{H}$. Comparison of contact angle measurement and microbial adhesion to solvents for assaying electron donor-electron acceptor (acid-base) properties of bacterial surface. Colloids Surf $B$ Biointerfaces $\quad 2008 ; \quad 65(1)$ : $134-139$. https://doi.org/10.1016/i.colsurfb.2008.03.010.

54. Azelmad K, Hamadi F, Mimouni R, Latrache H, Amzil K, Boulani AE, et al. Identification and physicochemical characterization of bacterial surface 
isolated from catering services in health establishment. Russ Open Med J 2016; 5: e0403. https://doi.org/10.15275/rusomj.2016.0403.

55. Abdallah $M$, Chataigne $G$, Ferreira-Theret $P$, Benoliel $C$, Drider $D$, Dhulster $\mathrm{P}$, et al. Effect of growth temperature, surface type and incubation time on the resistance of Staphylococcus aureus biofilms to disinfectants. Appl Microbiol Biotechnol 2014; 98(6): 2597-2607. https://doi.org/10.1007/s00253-013-5479-4.

56. Silva Meira QG, Barbosa IM, Athayde AJAA, Siqueira-Júnior JP, Souza EL. Influence of temperature and surface kind on biofilm formation by Staphylococcus aureus from food-contact surfaces and sensitivity to sanitizers. Food Control 2012; 25(2): 469-475. https://doi.org/10.1016/i.foodcont.2011.11.030.

57. Smith K, Hunter IS. Efficacy of common hospital biocides with biofilms of multi-drug resistant clinical isolates. J Med Microbiol 2008; 57(Pt 8): 966-973. https://doi.org/10.1099/imm.0.47668-0.

58. Morgan TD, Wilson M. The effects of surface roughness and type of denture acrylic on biofilm formation by Streptococcus oralis in a constant depth film fermentor. J Appl Microbiol 2001; 91(1): 47-53. https://doi.org/10.1046/j.1365-2672.2001.01338.x.

59. Steele A, Goddard D, Beech I. An atomic force microscopy study of the biodeterioration of stainless steel in the presence of bacterial biofilms. International Biodeterioration \& Biodegradation 1994; 34(1): 35-46. https://doi.org/10.1016/0964-8305(94)90018-3.

60. Wirtanen G, Salo S, Helander IM, Mattila-Sandholm T. Microbiological methods for testing disinfectant efficiency on Pseudomonas biofilm. Colloids Surf B Biointerfaces 2001; 20(1): $37-50$ https://doi.org/10.1016/S0927-7765(00)00173-9,

61. Røssvoll E, Langsrud S, Bloomfield S, Moen B, Heir E, Møretrø T. The effects of different hygiene procedures in reducing bacterial contamination in a model domestic kitchen. J Appl Microbiol 2015; 119(2): 582-593. https://doi.org/10.1111/jam.12869.

62. Takeo $Y$, Oie S, Kamiya A, Konishi H, Nakazawa T. Efficacy of disinfectants against biofilm cells of Pseudomonas aeruginosa. $\begin{array}{lll}\text { Microbios } & \text { 1994; } & \text { 19-26. }\end{array}$ https://www.ncbi.nlm.nih.gov/pubmed/8078416.

63. Oie $S$, Huang $Y$, Kamiya A, Konishi $H$, Nakazawa T. Efficacy of disinfectants against biofilm cells of methicillin-resistant Staphylococcus aureus. Microbios 1996; 85(345): 223-230. https://www.ncbi.nlm.nih.gov/pubmed/8699964.

Authors:

Khaddouj Amzil - PhD student, Laboratory of Microbial Biotechnology and Vegetal Protection, Faculty of Sciences University Ibn Zohr Agadir, Morocco. http://orcid.org/0000-0003-0050-4623.

Fatima Hamadi - Professor, Laboratory of Microbial Biotechnology and Vegetal Protection, Faculty of Sciences University Ibn Zohr Agadir, Morocco. http://orcid.org/0000-0002-9740-1948.

Rachida Mimouni - Professor, Laboratory of Microbial Biotechnology and Vegetal Protection, Faculty of Sciences University Ibn Zohr Agadir, Morocco. http://orcid.org/0000-0001-5950-8034.

Hassan Latrache - Professor, Laboratory of Bioprocess and Bio-interfaces, Faculty of Sciences and Techniques, Sultan Moulay Slimane University, Beni Mellal, Morocco. http://orcid.org/0000-0003-2297-9320.

Khadija Azelmad - Doctor, Laboratory of Microbial Biotechnology and Vegetal Protection, Faculty of Sciences University Ibn Zohr Agadir, Morocco. http://orcid.org/0000-0003-3118-9013.

Youssef Najih - Doctor, Laboratory of Bioprocess and Bio-interfaces, Faculty of Sciences and Techniques, Sultan Moulay Slimane University, Beni Mellal, Morocco. http://orcid.org/0000-0002-4334-9929.

Mustapha Mabrouki - Professor, Laboratory of Bioprocess and Biointerfaces, Faculty of Sciences and Techniques, Sultan Moulay Slimane University, Beni Mellal, Morocco. http://orcid.org/0000-0001-8975-9803. 